\title{
NOTÍCIAS DE UM PAÍS SELVAGEM: A LÍRICA ORIGINÁRIA DE RODRIGO PETRONIO
}

\author{
Patrícia Aparecida ANTONIO ${ }^{42}$
}

PETRONIO, R. Venho de um país selvagem. Rio de Janeiro: Topbooks, 2009. 104 p.

Por abandono dos deuses, teria a poesia contemporânea perdido o poder do canto? Teria ela, por desventura, perdido o fio e se esquecido daquilo que tivemos e temos desde o começo dos começos? Rodrigo Petronio, com o seu Venho de um país selvagem, publicado pela editora Topbooks, em 2009, é prova de que a poesia contemporânea ainda é a boa e grande poesia. Com isso, respondemos à primeira questão, dizendo que este conjunto de poemas assume o canto como talvez a sua característica mais marcante - coisa que, aparentemente, não encontra muito lugar na notável parcela instantânea, passadiça e midiática que se faz na poesia brasileira de hoje. Ou seja, aquela lírica que se emenda a imitar o que de superficial o mundo contemporâneo ou dito pós-moderno tem representado. O caso de Rodrigo Petronio é totalmente o contrário. A sua poesia é do tipo caudaloso, mas não daquele que se perde em si mesmo. Pontua quando deve, ritma quando deve, enxuga quando deve. É uma lírica de cadência livre porque coloca em seu elemento o eu-lírico, dando-lhe sopro, voz, carne. Mas, ainda assim, deixa clara a contenção, a necessidade e o desejo do cuidado com a palavra e a forma - "Quero ser estrangulado pelo canto que me liberta / Profundamente estrangulado pelo seu punho necessário" (PETRONIO, 2009, p.88), diz um dos poemas.

Poesia difícil? Não. Assim colocado, o eu-lírico demanda que a sua voz seja também a do leitor, pois a aventura que ali se empreende é de caráter marcadamente humano e precisa ser compreendida em seus dois extremos já mencionados, o da liberdade e o da restrição proporcionadas e impostas pela forma e pela própria palavra enquanto expressão. Só dessa forma compreendido, o verbo que anima estes poemas

\footnotetext{
${ }^{42}$ Mestranda (Bolsista FAPESP), Programa de Pós-Graduação em Estudos Literários, Faculdade de Ciências e Letras, Universidade Estadual Paulista, UNESP, campus de Araraquara, CEP 14800-901, Araraquara, SP, Brasil - gafinha@yahoo.com.br
} 
adquire existência frente ao mundo e às coisas que o cercam - "Nada mais separa porque tudo adere" (PETRONIO, 2009, p.93). Portanto, logo de início, é preciso entender o canto como (im)possibilidade da linguagem, do homem, da palavra. E, sobretudo, compreender a poesia como o canto do estrangeiro, daquele que vem de longe, daquele que está dentro e fora do mundo. Ora, de que se trata este título: Venho de um país selvagem? Aqueles mais criativos poderão entrever aqui o mito rimbaudiano, aquele mesmo do homem que se vê do lado de dentro de um mundo de cotidianidades e, instantaneamente, via poesia, se acha em outro completamente fulgurante e surpreendente, o país exótico e selvagem por todos desejado. De fato, talvez a melhor pedida quando se trata dessa obra seja mesmo observar esta condição de estrangeiro aliada à de um eu-lírico que se faz (ainda Rimbaud!) no "Je est un autre", que demanda a presença do leitor.

Nada mato. Nada retenho. Nada procrio.

Sou o parto azul dos elementos.

A circulação da linfa entre os dias e o spiritus.

Depois o poema vem cumprir sua rota.

Colide com o planeta. Abre uma ilha.

Por ora só me encontro em quanto ardo.

Exilado do corpo onde ainda queimo.

Refém da alma por quem fui amado.

Andarilho do mundo - não o adentro.

A flor ainda persiste em meio aos cacos.

Ruído vegetal: eis minhas armas.

Sou o que Sou:

Aqui me ofereço, novilho e cardo.

Morrer ignorado: maior de todos os monumentos.

A estrela pelo céu não deixa rastro.

Deus só nasce quando perde o centro.

(PETRONIO, 2009, p.31).

Para além disso, e pensando no teor místico-religioso da obra, só com a leitura do título fica a promessa da quebra dos limites (quaisquer que sejam), do novo que é trazido de muito longe, daquilo que se sonha experimentar, de todas as exentricidades possíveis. Com uma leitura mais atenta, a promessa se realiza e abre ao leitor um mundo de mitos, de temporalidades, de figuras, cujos limites são ultrapassados justamente no seu distanciamento. Neste ponto é que as coisas acabam se aproximando, como se contivéssemos todas elas refeitas no momento da leitura. Aparece, em pequeno, uma espécie de possibilidade de comunhão, de transcendência. Tudo pode estar ali. Mais um 
dos pontos-chave de Venho de um país selvagem (e aqui começamos a rascunhar a resposta à segunda questão que nos colocamos no início deste texto): o fato de que todos os poemas encerram um fundo paradoxal que coloca frente à frente o negativo e o positivo. Se todos os homens são iguais no que têm de pior, é preciso deslindar o feio, o sujo, o mal, é preciso conhecê-los antes de se alçar à tentativa de redenção ou de ressureição. Em outras palavras, para se chegar à plenitude ou, no limite, tateá-la, é preciso reforçar o que há de mal, de impuro, asseverando o caráter paradoxal da existência humana: "Entre a plenitude e o desespero: eis o homem. / Suando sua fraca anatomia, / Relógio de barro decaído, flauta adormecida" (PETRONIO, 2009, p.57). Com isso dizemos que a transcendência é tão somente avistada, mas nunca se torna realmente completa. A obra nos acena, em verdade, ao tropeço que é o homem - fato que, em nenhum momento deixa de ser bem-vindo pois que o que lhe vale o salto é, verdadeiramente, ser o que é.

Essa imperfeição fundamental e paradoxal encontra termo no amor e na morte (o retorno, o ciclo que se completa e recomeça), um vislumbre momentâneo de remissão. No que concerne ao amor, pode-se dizer que ele marca muito bem o misticismo transgressivo que é típico da poesia de Rodrigo Petronio (que já se observava em Pedra de luz). Bem à moda de Georges Bataille, a experiência da sexualidade, do erotismo (que é místico e tangencia o sagrado), confina com a morte, conduz à continuidade e refaz a unidade. Nesse sentido, o conhecimento só é possível no Outro, aquele que está próximo e distante (um papel que belamente pode caber ao leitor como num jogo de espelhos com este eu-lírico):

Sou o que Sou:

Duas faces de um mesmo ventre: tempo.

Duas moedas de um mesmo rosto: corpo.

Morro.

Eterno desconhecido.

Eternamente Outro.

(PETRONIO, 2009, p.24).

Por um outro lado, quando se trata da morte, ela aparece atrelada ao tempo e este como sendo uma pele que recobre toda a estrutura da carne. Em seu extremo, o que se encontra é um novo ciclo, maneira nova de comunhão e reinício, ou antes como nos 
versos finais do segundo poema de "Dentro da estrela branca", que pintam o corpo como monumento de sangue que escoa. Vale lembrar que ganham vida ainda nos poemas de Venho de um país selvagem outros motivos que são caros e clássicos quando o assunto é poesia lírica: a amada, o desejo, a vida, a redenção, os ancestrais, os deuses, a eternidade e o fim, dentre tantos.

Cabe observar, no entanto, como é grande a importância que o tempo toma nesse conjunto de poemas. É por meio de sua experiência que a dimensão do existir (poético, inclusive) propriamente se estabelece. O tempo obedece a uma estrutura que leva em conta o que permanece, pois que este eu-lírico é a terra, a chuva, as espáduas da amada, os avós, figuras rupestres, estas gravadas em seu próprio ser por meio da presentificação (no belo poema em duas partes intitulado "Retratos rupestres"). Nesse sentido, temos um eu-lírico de peso porque carrega em si todas as coisas já havidas, como se tudo o que já existiu estivesse ali no seu espaço e fosse parte do presente - "Em outro lugar já vivi este aqui e agora. / Outro era o tempo do mundo em minha pele." (PETRONIO, 2009, p.30). Esta concepção de tempo, que inclui todos os tempos, está no cerne mesmo destes poemas, pois o que temos aqui é o desejo de aproximação e afastamento de uma realidade original, primeva, eterna. Esta, sendo mitificada, acaba transmutando em mito cada momento presente (o da leitura, felizmente) e a poesia como um mundo que se nos é dado por meio da linguagem. A poesia, por seu turno, é aquela que proporciona a representação daquilo que imaginamos como os primórdios do real, um ambiente outro, distante e próximo, verdadeiramente selvagem, em que então o eu-lírico pode dizer "Venho de um país selvagem e todos os tempos do mundo são tempos de início" (PETRONIO, 2009, p.87). Forja-se um presente e uma realidade míticos em que se vê inserido o leitor. O poema (nos limites da palavra) traz notícias de um país selvagem, que de tão distante temos a certeza de estar sempre perto. E, na poesia, voltar ao início, procurar o começo do fio, é sempre garantia de bom termo. A lírica de Rodrigo Petronio faz isso. 